Catatan Penelitian

\title{
Mutu Kimia dan Organoleptik Tape Hasil Fermentasi Umbi Talas Kimpul (Xanthosoma sagittifolium) dengan Berbagai Konsentrasi Ragi
}

Quality of Chemical and Organoleptic Tape from Fermented Taro Kimpul (Xanthosoma sagittifolium) with Various Concentration of Yeast

Fariza Amelia Anisa*, V. Priyo Bintoro, Nurwantoro

Program Studi Teknologi Pangan, Fakultas Peternakan dan Pertanian, Universitas Diponegoro, Semarang

*Korespondensi dengan penulis (farizaamelia@gmail.com)

Artikel ini dikirim pada tanggal 28 Mei 2016 dan dinyatakan diterima tanggal 1 Agustus 2016. Artikel ini juga dipublikasi secara online melalui www.jatp.ift.or.id. Hak cipta dilindungi undang-undang. Dilarang diperbanyak untuk tujuan komersial.

Diproduksi oleh Indonesian Food Technologists® @2017

\begin{abstract}
Abstrak
Penelitian ini bertujuan untuk mengetauhi adanya perbedaan mutu kimia dan organoleptik tape hasil fermentasi umbi talas kimpul dengan berbagai konsentrasi ragi. Mutu kimia meliputi total padatan terlarut, kadar alkohol dan nilai $\mathrm{pH}$. Organoleptik meliputi rasa manis, rasa asam, tekstur dan kesukaan. Penelitian ini menggunakan ragi tape merk $\mathrm{Na}$ Kok Liong (NKL) dengan berbagai konsentrasi ragi $(0,25 \% ; 0,50 \% ; 0,75 \% ; 1,00 \%)$. Pengolahan data mutu kimia menggunakan Analysis of Variance (ANOVA) dan data organoleptik menggunakan Krusskal Wallis. Hasil penelitian menunjukan bahwa perlakuan berbagai konsentrasi ragi memberikan pengaruh nyata $(p<0,05)$ terhadap total padatan terlarut, kadar alkohol, nilai $\mathrm{pH}$ dan organoleptik rasa asam. Pada konsentrasi ragi $0,25 \%$ dihasilkan total padatan terlarut sebesar 11,6 ${ }^{\circ}$ Brix, kadar alkohol sebesar 8,85\%, nilai $\mathrm{pH}$ sebesar 4,85 dan organoleptik rasa asam dihasilkan dengan skor agak asam. Semakin besar konsentrasi ragi yang digunakan maka semakin tinggi kadar alkohol, semakin menurun total padatan terlarut dan semakin rendah nilai $\mathrm{pH}$. Pembuatan tape talas kimpul sebaiknya digunakan konsentrasi ragi dibawah 0,25\%.
\end{abstract}

Kata kunci : tape, umbi talas kimpul, konsentrasi ragi

\section{Abstract}

This study was aimed to reveal the differences in chemical and organoleptic quality of tape fermented taro kimpul with various concentrations of yeast. Quality chemicals include total dissolved solids, alcohol content and pH values. Organoleptic test used sweetness taste, sourness taste, texture and preference. This study used yeast tape brand of $\mathrm{Na} \mathrm{Kok} \mathrm{Liong} \mathrm{(NKL)} \mathrm{with} \mathrm{various} \mathrm{concentrations} \mathrm{of} \mathrm{yeast}(0.25 \% ; 0.50 \% ; 0.75 \%$; $1.00 \%)$. Data were analysed using Analysis of Variance (ANOVA) and data of organoleptic quality was used Krusskal Wallis to calculate. The results showed that the treatment of various concentrations of yeast had significant effect ( $p<0.05)$ of total dissolved solids, alcohol content, $\mathrm{pH}$ values and organoleptic sour taste. At a concentration of $0.25 \%$ yeast generated total dissolved solids of $11.6^{\circ}$ Brix, the alcohol content of $8.85 \%$, the pH value of 4.85 and organoleptic of sourness taste were slightly acidic. The higher concentration of yeast, the higher alcohol content, the lower at total dissolved solids and the lower at $\mathrm{pH}$ value. Tape taro kimpul should be used in yeast concentration below $0.25 \%$.

Keywords: tape, taro timpul, concentration of yeast

\section{Pendahuluan}

Tanaman pangan sumber karbohidrat memiliki peranan penting dalam menjaga ketahanan pangan di Indonesia. Salah satu contohnya yaitu tanaman talas sebagai sumber karbohidrat yang terdiri dari beberapa varietas. Pada umumnya, bagian dari tanaman talas yang dapat dipanen adalah umbinya. Salah satu umbi dari varietas talas yang memiliki kandungan karbohidrat cukup tinggi adalah umbi talas kimpul (Xanthosoma sagittifolium). Menurut Tabel Komposisi Pangan Indonesia (2009), kandungan karbohidrat yang terdapat dalam umbi talas kimpul adalah sebesar 34,2 g/100 g.

Tape adalah makanan tradisional yang mudah dalam pengolahannya dan tidak membutuhkan biaya mahal. Tape merupakan makanan khas olahan dari aneka bahan pangan yang mengandung karbohidrat. Proses pembuatan tape melalui proses fermentasi diperlukan ragi tape yang akan mengubah karbohidrat dalam bahan menjadi gula dan alkohol (Rukmana dan Yuniarsih, 2001).
Didalam ragi tape mengandung beberapa mikroba seperti kapang, khamir dan bakteri. Kapang Amylomyces rouxii dan Candida pellicullosa termasuk dalam organimse yang bersifat amilolitik kuat. Khamir Saccharomyces cerevisiae merupakan sugar fermenter kuat yang menguraikan gula menjadi etanol dengan kadar etanol yang tinggi, berbeda dengan Hansenula anomala yang relatif tidak tinggi dalam menghasilkan kadar etanol. Bakteri Acetobacter spp. yang menguraikan etanol menjadi asam asetat dan sering bekerja sama dengan yeast dalam fermentasi alkohol (Owens, 2015).

Dari sebuah penelitian bahwa mikroba yang paling berperan dalam proses fermentasi tape adalah kapang Chlamydomucor oryzae (Amylomyces rouxii), khamir Endomycosis (Saccharomycopsis) burtonii dan Saccharomyces cereviseae. Proses fermentasi tape dibagi menjadi dua tahap yaitu perubahan pati menjadi gula oleh kerja kapang dan perubahan gula menjadi alkohol oleh kerja khamir (Raharjanti, 2006). 
Tujuan dari penelitian ini adalah untuk mengetahui mutu kimia (total padatan terlarut, kadar alkohol, nilai $\mathrm{pH}$ ) dan organoleptik tape hasil fermentasi umbi talas kimpul yang diberi berbagai konsentrasi ragi. Manfaat yang dapat diperoleh dari penelitian ini adalah mendapatkan informasi mengenai perbedaan mutu kimia (total padatan terlarut, kadar alkohol, nilai $\mathrm{pH}$ ) dan organoleptik tape hasil fermentasi umbi talas kimpul dengan berbagai konsentrasi ragi serta penggunaan konsentrasi ragi yang sesuai untuk menghasilkan tape umbi talas kimpul yang berkualitas.

\section{Materi dan Metode \\ Materi}

Materi yang digunakan dalam penelitian ini adalah umbi talas kimpul, ragi tape Na Kok Liong (NKL) dengan kepadatan 2,4 × $10^{8} \mathrm{CFU} / \mathrm{g}$, daun pisang, besek, aquades, alat pengukus, nampan, baskom, kompor, pisau, sendok, timbangan, pipet tetes, piknometer, labu ukur, alat destilasi, erlenmeyer, refraktometer, dan $\mathrm{pH}$ meter.

\section{Metode}

Penelitian ini telah dilaksanakan pada bulan Desember 2015 - Februari 2016 di Laboratorium Kimia dan Gizi Pangan, Jurusan Pertanian, Fakultas Peternakan dan Pertanian, Universitas Diponegoro, Semarang. Rancangan percobaan yang digunakan adalah Rancangan Acak Lengkap (RAL) dan respon yang diamati adalah mutu kimia (kadar alkohol, total padatan terlarut, nilai $\mathrm{pH}$ ) dan organoleptik. Perlakuan yang diberikan dibagi dalam 4 taraf dengan 5 kali ulangan. Adapun taraf perlakuan yang diterapkan yaitu:

T1 : Konsentrasi ragi tape $0,25 \%$ dari berat umbi

T2 : Konsentrasi ragi tape $0,50 \%$ dari berat umbi

T3 : Konsentrasi ragi tape $0,75 \%$ dari berat umbi

T4 : Konsentrasi ragi tape $1,00 \%$ dari berat umbi

\section{Pembuatan Tape Umbi Talas Kimpul}

Bahan utama umbi talas kimpul, dicuci bersih. Kemudian, direbus selama 30 menit. Kulit umbi talas kimpul dikupas bersih dan dagingnya dipotong bentuk balok dengan ukuran $10 \times 3 \times 2 \mathrm{~cm}$. Lalu, ditimbang sebanyak $100 \mathrm{~g}$ untuk setiap unit percobaan. Setelah suhu umbi kimpul sama dengan suhu kamar, ditaburi ragi dengan konsentrasi ragi sesuai perlakuan $0,25 \%$; $0,50 \% ; 0,75 \%$; dan $1,0 \%$ dari berat umbi talas kimpul. Umbi talas kimpul yang telah diberi ragi, dibungkus dengan daun pisang dan disimpan dalam besek pada suhu ruang selama 2 hari (48 jam) agar fermentasi berjalan sempurna (Rukmana dan Yuniarsih termodifikasi, 2001).

\section{Analisis Statistik}

Data mutu kimia (total padatan terlarut, kadar alkohol, nilai $\mathrm{pH}$ ) yang diperoleh, kemudian dianalisis dengan Analysis of Variance (ANOVA) dan apabila signifikan dilanjutkan dengan uji lanjut Duncan. Hasil dari organoleptik diuji normalitasnya dengan uji KolmogorovSmirnov, dilanjutkan dengan uji non parametric Kruskal Wallis selanjutnya apabila signifikan dilakukan uji lanjut
Mann Whitney. Analisis ini dilakukan dengan menggunakan SPSS 16.0 Statistic Software.

\section{Total Padatan Terlarut}

Pengukuran kadar total padatan terlarut dilakukan dengan refraktometer. Refraktometer dikalibrasi terlebih dahulu dengan aquades dan dikeringkan dengan menggunakan tisu. Sebanyak $5 \mathrm{~g}$ tape di peras dengan kain saring hingga mendapat sari tapenya. Selanjutnya, diteteskan pada permukaan prisma refraktometer, kemudian prisma ditutup dan dipastikan tidak ada gelembung udara. Pembacaan skala indeks bias dilihat pada lubang pengamat refraktometer (Legowo et al., 2005)

\section{Kadar Alkohol}

Metode pengujian kadar alkohol dilakukan dengan menggunakan metode piknometer (Azizah et al., 2012). Sampel dihaluskan sebanyak $100 \mathrm{~g}$ dimasukkan dalam labu ukur kemudian ditambahkan aquades sebanyak $100 \mathrm{ml}$ selanjutnya didestilasi hingga suhu $110^{\circ} \mathrm{C}$. Destilat ditampung di erlenmeyer hingga volume $20 \mathrm{ml}$. Destilat kemudian dimasukan kedalam piknometer yang sebelumnya telah diketahui beratnya. Destilat dimasukkan hingga memenuhi piknometer, kelebihan destilat pada puncak pipa kapiler dibersihkan. Permukaan luar piknometer dikeringkan dengan kertas tisu dan ditimbang beratnya. Selanjutnya, prosedur yang sama dilakukan pada aquades sebagai pembanding. Berdasarkan hasil perhitungan berat jenis alkohol yang diperoleh, dapat diketahui kadar alkohol yang terkandung dengan mengonversikannya menggunakan tabel konversi BJ alkohol. Tabel konversi BJ alkohol terdapat dalam buku Perry Chemical Engineers Handbook. Selanjutnya, dicari kadar alkohol dalam larutan sampel dengan cara memasukkan pada kurva standar menggunakan persamaan garis lurus dari kurva standar yaitu $y=-0,0016 x+0,9949$.

\section{Nilai $\mathrm{pH}$}

Cara menggunakan $\mathrm{pH}$ meter yang pertama adalah $\mathrm{pH}$ meter harus distandarisasi dengan larutan buffer standar ( $\mathrm{pH} 4$ dan $\mathrm{pH}$ 7). Elektroda pada $\mathrm{pH}$ meter dicelupkan dalam larutan buffer, dibilas dengan air dan dikeringkan (Harrigan, 1998). Sampel tape diambil $1 \mathrm{~g}$ lalu ditambahkan aquades sebanyak $9 \mathrm{ml}$. Kemudian, elektroda dicelupkan untuk mengukur sampel dan $\mathrm{pH}$ muncul di monitor.

\section{Organoleptik}

Uji organoleptik menggunakan cara kerja uji skoring, 25 panelis diminta memberikan skor sesuai dengan kesan yang diperoleh dari kriteria yang diberikan dalam form kuisioner dengan skala 1 sampai 4 . Panelis diminta untuk menguji dengan kriteria rasa manis, rasa asam, tekstur dan kesukaan (Koswara, 2006)

\section{Hasil dan Pembahasan \\ Total Padatan Terlarut \\ Berdasarkan Tabel 1 dapat diketahui bahwa konsentrasi ragi yang semakin meningkat menghasilkan total padatan terlarut yang semakin menurun. Hal ini}


dikarenakan dengan banyaknya jumlah inokulum yang ditambahkan dalam pembuatan tape umbi talas kimpul, menyebabkan banyaknya kandungan pati yang dibongkar oleh enzim amilase menjadi dekstrin menjadi maltosa menjadi gula. Selanjutnya, gula cepat diubah oleh khamir menjadi alkohol, asam, dan $\mathrm{CO}_{2}$. Sependapat dengan pernyataan Owens (2015) bahwa kapang Amylomycess rouxii memiliki aktifitas amilolitik yang menghasilkan enzim amilase, dengan mengubah pati menjadi gula (maltosa dan glukosa). Jumlah kapang dan menurunnya total gula (termasuk didalamnya polisakarida) berhubungan dengan kadar alkohol yang meningkat.

Pada tape umbi talas kimpul yang difermentasi dengan berbagai konsentrasi ragi selama 48 jam menghasilkan total padatan terlarut terendah pada konsentrasi ragi T4 (1,00\%) sebesar 11,6 ${ }^{\circ}$ Brix dan total padatan terlarut tertinggi pada konsentrasi ragi $\mathrm{T} 1$ $(0,25 \%)$ sebesar $20,2^{\circ}$ Brix. Komponen total padatan terlarut dalam tape kimpul diduga adalah dekstrin (oligosakarida), maltosa (disakarida) dan glukosa (monosakarida) yang mana ketiganya dapat larut dalam air. Hal ini sesuai dengan pendapat Hutagalung (2004) bahwa dekstrin adalah zat antara hasil pemecahan amilum yang mana molekulnya lebih sederhana dan lebih mudah larut dalam air, maltosa terdiri dari dua molekul glukosa yang lebih mudah dicerna dan glukosa merupakan gula sederhana yang larut dalam air serta rasanya manis. Pendapat ini diperkuat oleh Djatati et al. (2013) bahwa adanya komponen dektsrin yang terdapat pada filtrat tape umbi talas berpengaruh pada total padatan terlarut dan rendemen.

\section{Kadar Alkohol}

Tabel 1 menunjukan peningkatan konsentrasi ragi tape adalah berbanding lurus dengan meningkatnya kadar alkohol tape umbi talas kimpul. Semakin tinggi konsentrasi ragi yang ditambahkan pada pembuatan tape umbi talas kimpul, berarti semakin banyak inokulum yang bekerja dalam proses fermentasi menyebabkan gula cepat diubah menjadi alkohol. Hal ini sependapat dengan Santi (2008) bahwa penambahan inokulum berpengaruh terhadap hasil alkohol, dengan bertambahnya inokulum maka kerja khamir Saccharomyces cerevisiae makin cepat untuk mengubah gula menjadi alkohol sehingga menghasilkan kadar alkohol yang tinggi. Kadar alkohol tape umbi talas kimpul yang tinggi disebabkan peran khamir Saccharomyces cerevisiae dalam ragi tape sebagai fermenter kuat penghasil alkohol. Sesuai dengan pendapat Owens (2015) bahwa Saccharomyces cerevisiae tidak bersifat amilolitik, dikarenakan pertumbuhannya dalam bahan pangan berkabohidrat tergantung dari mikroba yang menghasilkan gula. Saccharomyces cerevisiae merupakan sugar fermenter kuat yang menguraikan gula menjadi etanol dengan kadar etanol yang tinggi.

Tape hasil fermentasi umbi talas kimpul dengan berbagai konsentrasi ragi yang difermentasi selama 48 jam menghasilkan kadar alkohol terendah diperoleh pada konsentrasi ragi $\mathrm{T} 1(0,25 \%)$ sebesar $8,85 \%$ dan kadar alkohol tertinggi diperoleh pada konsentrasi ragi T4 (1,00\%) sebesar $11,56 \%$. Nilai ini menunjukan hasil yang tidak jauh beda dengan penelitian Yulianti (2014) bahwa kadar alkohol dengan lama fermentasi 48 jam pada tape beras sebesar $7,72 \%$; tape ketan hitam sebesar $6,95 \%$ dan tape singkong sebesar 7,12\%. Perbedaan kadar alkohol tape umbi talas kimpul dengan tape lainnya disebabkan perbedaan kandungan karbohidrat yang dimiliki pada masing - masing bahan. Hal ini sependapat dengan Yulianti (2014) bahwa kandungan karbohidrat pada masing - masing bahan fermentasi akan menghasilkan kadar alkohol yang berbeda pula. Semakin tinggi kandungan karbohidrat pada bahan, semakin tinggi pula kadar alkoholnya.

\section{Nilai $\mathrm{pH}$}

Tabel 1 menunjukan bahwa konsentrasi ragi yang semakin meningkat menghasilkan nilai $\mathrm{pH}$ yang semakin menurun menyebabkan kondisi semakin asam. Banyaknya inokulum yang ditambahkan menghasilkan semakin besarnya khamir memproduksi alkohol (etanol) sehingga semakin banyak hasil metabolit berupa asam -asam organik. Hal ini sesuai dengan pendapat Santosa dan Prakosa (2010) bahwa semakin tinggi konsentrasi ragi digunakan, kadar asam tape semakin meningkat

Tabel 1. Hasil Kadar Alkohol, Total Padatan Terlarut dan Nilai pH Tape Umbi Talas Kimpul dengan Berbagai Konsentrasi Ragi

\begin{tabular}{cccc}
\hline \multirow{2}{*}{ Perlakuan } & \multicolumn{3}{c}{ Rerata } \\
\cline { 2 - 4 } & Total Padatan Terlarut ( ${ }^{\circ}$ Brix $)$ & Kadar Alkohol (\%) & Nilai $\mathrm{pH}$ \\
\hline T1 & $20,2 \pm 1,09^{\mathrm{a}}$ & $8,85 \pm 1,15^{\mathrm{a}}$ & $4,85 \pm 0,22^{\mathrm{a}}$ \\
T2 & $19,8 \pm 1,48^{\mathrm{a}}$ & $9,62 \pm 1,29^{\mathrm{ab}}$ & $4,76 \pm 0,12^{\mathrm{ab}}$ \\
T3 & $12,8 \pm 1,09^{\mathrm{b}}$ & $10,88 \pm 0,92^{\mathrm{bc}}$ & $4,61 \pm 0,11^{\mathrm{bc}}$ \\
T4 & $11,6 \pm 2,40^{\mathrm{b}}$ & $11,56 \pm 0,88^{\mathrm{c}}$ & $4,50 \pm 0,18^{\mathrm{c}}$ \\
\hline
\end{tabular}

Keterangan: superskrip yang berbeda pada kolom yang sama menunjukan perbedaan nyata $(p<0,05)$

Tabel 2. Hasil Organoleptik Tape Umbi Talas Kimpul dengan Berbagai Konsentrasi Ragi

\begin{tabular}{ccccc}
\hline Perlakuan & Rasa Manis & Rasa Asam & Tekstur & Kesukaan \\
\hline T1 & $1,6 \pm 0,67^{\text {ns }}$ & $2,6 \pm 0,70^{\text {a }}$ & $2,3 \pm 0,66^{\text {ns }}$ & $1,8 \pm 0,70^{\text {ns }}$ \\
T2 & $1,7 \pm 0,68^{\text {ns }}$ & $2,7 \pm 0,65^{\text {a }}$ & $2,5 \pm 0,74^{\text {ns }}$ & $2,0 \pm 0,62^{\text {ns }}$ \\
T3 & $1,5 \pm 0,57^{\text {ns }}$ & $3,1 \pm 0,77^{\text {b }}$ & $2,4 \pm 0,66^{\text {ns }}$ & $1,7 \pm 0,78^{\text {ns }}$ \\
T4 & $1,8 \pm 0,86^{\text {ns }}$ & $2,6 \pm 0,69^{\text {a }}$ & $2,7 \pm 0,58^{\text {ns }}$ & $2,1 \pm 0,83^{\text {ns }}$ \\
\hline
\end{tabular}

Keterangan: ${ }^{\mathrm{ns}}=$ tidak signifikan. Huruf superskrip berbeda pada kolom yang sama menunjukan perbedaan nyata $(p<0,05)$ 
dikarenakan kemampuan ragi untuk menguraikan gula menjadi alkohol lebih besar sehingga reaksi pemecahan alkohol menjadi asam oleh bakteri pembentuk asam semakin besar dan menurunkan nilai $\mathrm{pH}$. Ditambahkan oleh Owens (2015) bahwa bakteri Acetobacter spp. yang menguraikan etanol menjadi asam asetat dan sering bekerja sama dengan yeast dalam fermentasi alkohol. Selain itu, ditemukan dalam tape bakteri asam laktat yang menghasilkan asam laktat.

Nilai $\mathrm{pH}$ pada tape umbi talas kimpul yang difermentasi selama 48 jam, didapatkan nilai $\mathrm{pH}$ tertinggi pada konsentrasi ragi $\mathrm{T} 1(0,25 \%)$ sebesar 4,85 dan nilai $\mathrm{pH}$ terendah pada konsentrasi ragi T4 (1,00\%) sebesar 4,50 . Nilai $\mathrm{pH}$ pada tape umbi talas kimpul ini tidak berbeda jauh dibandingkan dengan tape - tape pada umunya. Hal ini dibuktikan dengan penelitian Simbolon (2008) bahwa nilai $\mathrm{pH}$ yang dihasilkan dari fermentasi tape ubi jalar ungu dengan semakin banyaknya konsentrasi ragi didapatkan nilai $\mathrm{pH}$ yang semakin menurun pada konsentrasi ragi $0,25 \%$ sebesar 5,50 dan pada konsentrasi ragi $1,00 \%$ sebesar 4,62 . Pada tape beras ketan menurut Owens (2015) bahwa $\mathrm{pH}$ yang dihasilkan berkisar antara 4,00 sampai 4,20.

\section{Organoleptik}

Berdasarkan Tabel 2 dapat diketahui organoleptik rasa manis, tekstur dan kesukaan menunjukan hasil tidak signifikan berarti terdapat pengaruh tidak nyata ( $p>0,05)$ sehingga tidak dilakukan uji lanjut. Namun, pada organoleptik rasa asam diperoleh hasil signifikan yang berarti terdapat pengaruh nyata $(p<0,05)$ sehingga dilakukan uji lanjut.

Tabel 2 menunjukan bahwa organoleptik rasa manis, tekstur dan kesukaan pada tape umbi talas kimpul dengan berbagai konsentrasi ragi T1 $(0,25 \%)$, T2 $(0,50 \%)$, T3 $(0,75 \%)$ dan T4 $(1,00 \%)$ dapat diketahui tidak adanya perbedaan akibat perlakuan. Hasil organoleptik rasa asam pada tape hasil fermentasi umbi talas kimpul dengan berbagai konsentrasi ragi $\mathrm{T} 1$ $(0,25 \%)$, T2 $(0,50 \%)$, T3 $(0,75 \%)$ dan T4 $(1,00 \%)$ diperoleh masing - masing sebesar 2,6 skor agak asam; 2,7 skor agak asam; 3,1 skor asam dan 2,6 skor agak asam. Semakin besar konsentrasi ragi tape umbi talas kimpul yang digunakan, maka semakin besar nilai organoleptik rasa asam yang dihasilkan. Rasa asam yang dihasilkan disebabkan dari hasil metabolit penguraian pati menjadi alkohol, asam dan $\mathrm{CO}_{2}$. Hal ini sesuai dengan pendapat Owens (2015) bahwa selain dari produksi glukosa, asam laktat dan etanol yang memberikan rasa tape yang manis - asam sedikit aroma alkohol, terdapat mikroba yang digunakan dalam fermentasi juga menghasilkan produk metabolit lain yang berperan dalam rasa dan aroma tape, seperti etil asetat yang dihasilkan pada tape memberikan aroma khas yang kuat. Perbedaan rasa asam yang dihasilkan oleh panelis pada perlakuan tape umbi talas kimpul dengan berbagai konsentrasi ragi dikarenakan ketajaman pengecapan yang dimiliki masing - masing orang berbeda.

Hal ini sesuai dengan pendapat Hutapea (2006) bahwa perbedaan ketajaman pengecapan diakibatkan perbedaan dari segi faktor keturunan, ada yang memiliki puting pengecap (taste buds) rasa asam yang lebih peka dibandingkan puting pengecap rasa lainnya sehingga terasa dominan rasa asam. Selain itu, air liur masing masing orang memiliki cita rasa yang berbeda dan akan mempengaruhi cita rasa makanan yang dicicipinya.

\section{Kesimpulan}

Berdasarkan hasil penelitian yang diperoleh, semakin besar konsentrasi ragi yang digunakan maka semakin menurun total padatan terlarut, semakin tinggi kadar alkohol, dan semakin rendah nilai $\mathrm{pH}$. Total padatan terlarut terendah konsentrasi ragi $1,00 \%$ sebesar $11,6^{\circ}$ Brix dan tertinggi konsentrasi ragi 0,25\% sebesar 20,2 ${ }^{\circ}$ Brix. Kadar alkohol terendah konsentrasi ragi $0,25 \%$ sebesar $8,85 \%$ dan tertinggi konsentrasi ragi $1,00 \%$ sebesar $11,56 \%$. Nilai $\mathrm{pH}$ tertinggi konsentrasi ragi $0,25 \%$ sebesar 4,85 dan nilai $\mathrm{pH}$ terendah konsentrasi ragi $1,00 \%$ sebesar 4,50 . Organoleptik rasa asam terendah konsentrasi ragi $0,25 \%$ dengan skor agak asam dan tertinggi konsentrasi ragi 0,75\% dengan skor asam. Pada pembuatan tape umbi talas kimpul, sebaiknya konsentrasi ragi yang digunakan adalah kurang dari 0,25\% karena kadar alkohol yang dihasilkan sampai konsentrasi ragi $0,25 \%$ paling rendah.

\section{Daftar Pustaka}

Azizah, N., Al-Baarri, A.N., Mulyani, S. 2012. Pengaruh lama fermentasi terhadap kadar alkohol, $\mathrm{pH}$, dan produksi gas pada proses fermentasi bioetanol dari whey dengan substitusi kulit nanas. J. Aplikasi Teknologi Pangan 2 (1) : $72-77$.

Direktorat Jenderal Tanaman Pangan. 2013. Kimpul ( $X$. sagittifolium Schott.). Lembar Informasi Direktorat Budidaya Aneka Kacang dan Umbi. Kementrian Pertanian. Jakarta.

Djatati, S., Jariyah, Mawarti, T.I. 2013. Pembuatan brem padat dengan substitusi filtrat tape umbi talas. EJournal UPN Veteran Jatim.

Green, D.W., Perry, R.H. 2008. Perry's Chemical Engineers' Handbook $8^{\text {th }}$ Edition. The McGraw-Hill Companies, Inc.

Harrigan, W.F. 1998. Laboratory Methods in Food Microbiology $3^{\text {rd }}$ Edition. Academic Press. California,

Hutagalaung, H. 2004. Karbohidrat. USU Digital Library. Bagian IImu Gizi Fakultas Kedokteran. Universitas Sumatera Utara.

Hutapea, A.M. 2006. Keajaiban - Keajaiban dalam Tubuh Manusia. Gramedia Pustaka Utama. Jakarta.

Koswara, S. 2006. Pengujian Organoleptik (Evaluasi Sensori) dalam Industri Pangan. Ebook Pangan.

Legowo, A.M., Nurwantoro, Sutaryo. 2005. Analisis Pangan. Badan Penerbit Universitas Diponegoro. Semarang.

Owens, J.D. 2015. Indigenous Fermented Foods of Southeast Asia. CRC Press, Taylor and Francis Group. Boca Raton Florida.

Persatuan Ahli Gizi Indonesia. 2009. Tabel Komposisi Pangan Indonesia. Jakarta.

Raharjanti, D.S. 2006. Penghambatan Pertumbuhan Aspergillus parasiticus dan Reduksi Aflatoksin 
oleh Kapang dan Khamir Ragi Tape. Tesis Pascasarjana Institut Pertanian Bogor.

Rukmana, R., Yuniarsih, Y. 2001. Aneka Olahan Ubi Kayu. Kanisius. Yogyakarta.

Santi, S.S. 2008. Pembuatan alkohol dengan proses fermentasi buah jambu mete oleh khamir Sacharomices cerevesiae. J. Penelitian IImu Teknik Kimia 8 (2): $104-111$.
Santosa, A., Prakosa, C. 2010. Karakteristik tape buah sukun hasil fermentasi penggunaan konsentrasi ragi yang berbeda. J. Unwidha 22 (73): $48-55$.

Simbolon, K. 2008. Pengaruh Presentase Ragi Tape dan Lama Fermentasi Terhadap Mutu Tape Ubi Jalar. Skripsi. Fakultas Pertanian Universitas Sumatera Utara.

Yulianti, C.H. 2014. Uji Beda kadar alkohol pada tape beras, ketan hitam dan singkong. J. Teknika 6 (1) : 531- 536 . 